\begin{tabular}{|l|l|l||}
\hline \multicolumn{2}{|c|}{ PublisherInfo } \\
\hline \hline PublisherName & $:$ & BioMed Central \\
\hline \hline PublisherLocation & $:$ & London \\
\hline \hline PublisherImprintName & $:$ & BioMed Central \\
\hline \hline
\end{tabular}

\title{
Malarial origins
}

\begin{tabular}{|l|l|l||}
\hline \multicolumn{2}{|c||}{ ArticleInfo } \\
\hline \hline ArticleID & $:$ & 3886 \\
\hline \hline ArticleDOI & $:$ & $10.1186 /$ gb-2001-2-10-reports0036 \\
\hline \hline ArticleCitationID & $:$ & reports0036 \\
\hline \hline ArticleSequenceNumber & $:$ & 18 \\
\hline \hline ArticleCategory & $:$ & Paper report \\
\hline \hline ArticleFirstPage & $:$ & 1 \\
\hline \hline ArticleLastPage & $:$ & 4 \\
\hline \hline & & RegistrationDate : 2001-8-7 \\
ArticleHistory & $:$ & Received \\
& & OnlineDate $2001-8-7$ \\
\hline \hline ArticleCopyright & $:$ & BioMed Central Ltd2001-9-19 \\
\hline \hline ArticleGrants & $:$ & \\
\hline \hline
\end{tabular}




\begin{tabular}{|l|l|l|}
\hline ArticleContext & $:$ & 13059221010 \\
\hline
\end{tabular}

\section{S Subramanian}

\section{Abstract}

All members of the species Plasmodium falciparum seem to have been derived from a single recent ancestor.

\section{Significance and context}

The protozoan parasite Plasmodium falciparum causes malaria in humans. Its transmission and pathogenesis benefit from its genetic variation, which seriously affects attempts to combat this potentially deadly disease. An interesting feature of the malaria parasite is that DNA variation at silent that is synonymous - sites in the coding sequences is very low, because of constraints in codon usage, whereas genetic variation in the proteins that act as antigenic determinants, or are involved in drug resistance or pathogenesis, is fairly large. On the other hand, microsatellite variation exists within and among subpopulations of $P$. falciparum. To investigate this genetic variation, the authors addressed the question of whether all extant $P$. falciparum cells have been derived from a single progenitor that spread through the human population by analyzing the intronic sequences of various $P$. falciparum genes. Introns are among the most rapidly evolving sequences in eukaryotes and are often used in studies of population structure.

\section{Key results}

Volkman et al. analyzed 25 intronic sequences from eight independent isolates of $P$. falciparum from various geographical locations and found only eight single-nucleotide polymorphisms (SNPs), of which five occurred within microsatellite repeats. The authors could identify repeats (of 1 to 8 base-pairs in length) among all the introns analyzed. Out of these 71 microsatellite repeats, $51 \%$ were monomorphic and $49 \%$ were polymorphic, with two or more alleles. The authors suggest that the high level of genetic diversity is generated as a consequence of replication slippage. Their results on microsatellite polymorphisms support the hypothesis of a recent progenitor and imply a high mutation rate for the creation of microsatellite repeats and that microsatellite variation in P. falciparum is widespread within introns. They also found that SNPs within introns are rare. Although SNPs occur in both introns and exons, the selection pressure on coding sequences results in fewer polymorphisms within coding regions. The results suggest that the antigenic variation associated with these repeated amino acid sequences has occurred within P. falciparum, rather than by lateral transfer or some other mechanism. 
The results are supported by analysis of mitochondrial DNA, which was found to be identical in nucleotide sequence among diverse isolates of $P$. falciparum.

\title{
Links
}

Supplementary data to Science 293:482-484, containing additional methods and figures, is freely available.

\section{Conclusions}

The analysis establishes the recent origin of all extant $P$. falciparum and furthermore provides an explanation for the diversity observed in genes for $P$. falciparum antigens and other selected proteins.

\section{Reporter's comments}

Although the authors propose a hypothesis of a single recent common ancestor for all $P$. falciparum on the basis of their data, alternative explanations have been proposed by others. The complete sequencing of the $P$. falciparum genome, now underway, will increase our knowledge of the biology of this pathogen and facilitate attempts to combat malaria.

\section{Table of links}

\author{
Science
}

Supplementary data to Science 293:482-484 


\section{References}

1. Volkman SK, Barry AE, Lyons EJ, Nielsen KM, Thomas SM, Choi M, Thakore SS, Day KP, Wirth DF, Hartl DL: Recent origin of Plasmodium falciparum from a single progenitor. Science. 2001, 293: 482-484. 0036-8075

This PDF file was created after publication. 